International Journal of Social Sciences and Humanities
Available online at http://sciencescholar.us/journal/index.php/ijssh
Vol.1 No. 3, December 2017, pages: 88 96
e-ISSN: 2550-7001, p-ISSN: 2550-701X
http://dx.doi.org/10.21744/ijssh.v1i3.59

\title{
Constructing Assessment Instrument Models for Teacher's Performance, Welfare and Education Quality
}

\begin{abstract}
Crossiark
Wayan Maba ${ }^{a}$, Ida Bagus Ketut Perdata ${ }^{b}$, I Nengah Astawa $^{c}$

Article history: Received 8 July 2017, Accepted in revised form 14 November 2017, Approved 29 November 2017 Available online 14 December 2017

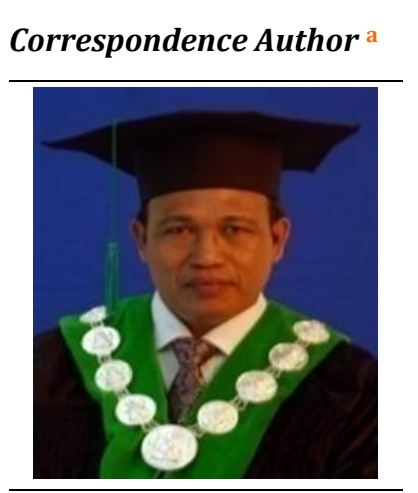

Keywords

Assessment;

Instrument;

Performance;

Quality;

Welfare;

\section{Abstract}

The prime objective of this research is to design teacher performance assessment instrument model, teacher welfare instrument model, and instrument model of education quality improvement. To achieve these objectives needs analysis, potential field analysis, and other supporting analyzes were performed. The final product or outcome of this research is a set of assessment instrument models for teachers' performance, teachers' welfare, and educational quality improvement. The study was designed for two years adopting the Research and Development theory employing 4D model consisting of Define, Design, Develop, and Disseminate. The first year designated as a phase of Define and Design, aims to design a draft of the assessment instrument models. The second year, the activity was focused on the refinement of the final draft of the assessment instrument models for teacher performance, teachers' welfare, and quality of education outcomes through focus group discussion (FGD) with the selected teachers, principals and school supervisors. The final research result is a set of valid assessment models of teachers' performance, teachers' welfare, and quality improvement of education.
\end{abstract}

e-ISSN : 2550-7001, p-ISSN : 2550-701X@ Copyright 2017. The Author. SS Journals Published by Universidad Técnica de Manabí.

This is an open-access article under the CC BY-SA 4.0 license

(https://creativecommons.org/licenses/by-sa/4.0/)

All rights reserved.

a Mahasaraswati University, Denpasar, Bali, Indonesia (baguspapers@gmail.com)

b Mahasaraswati University, Denpasar, Bali, Indonesia (karmabudya@yahoo.com)

c Mahasaraswati University, Denpasar, Bali, Indonesia (nengah_astawa@yahoo.com) 


\section{Contents}

Abstract

1. Introduction

2. Research Method

90

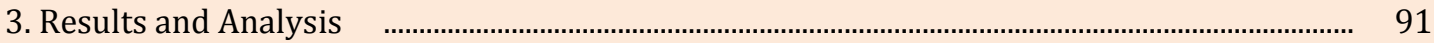

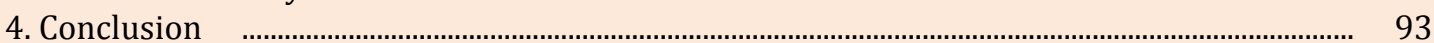

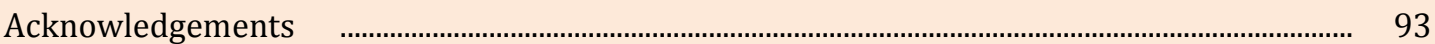

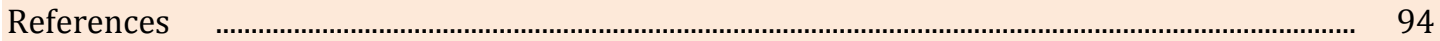

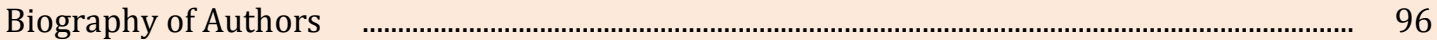

\section{Introduction}

Education is absolutely important in our life nowadays. Without a good education, people cannot survive in facing this highly competitive globalization. A teacher is one of an essential element in education. Poor quality of education is largely determined by teacher quality standards. Therefore, teachers need to continually improve their competencies as stated in Law Number 14, in 2005 regarding Teachers and Lecturers. There are four competencies that must be met by the teachers, namely pedagogic, personality, professional, and social competence. In conjunction with the competency standards of teachers in Indonesia, as a matter of fact, that teachers' competence still needs to be improved to gain a higher level of education quality. ${ }^{1}$

Teachers' competence assessment in the last three years showed that the result of standardization still needs to be improved to reach the target of education service standard for teachers' competency. ${ }^{2}$ The Ministry of Education and Culture recognized this situation and anticipated it by creating a standard mapping of teachers' competence in Indonesia. ${ }^{3}$ There are various training has been conducted to improve teachers' competence, including teacher training by adopting several strategies including the utilization educational technology. ${ }^{4}$

Improving teaching and learning facilities is also an important factor in improving teachers' competence. Teachers have been provided with several multimedia equipments to enhance their ways of teaching to be more effective and easier to achieve the learning objectives. Activities such as training, briefing, and teacher empowerment are certainly essential to improve their quality of the teachers. All these efforts were expected to increase the professional competence of teachers and give a positive impact on the improvement of the quality of students. Therefore it can be said that by improving teachers' quality standards in Indonesia, the quality of education will increase significantly. After all, education is something very important. ${ }^{5}$

Additionally, to achieve an increase in the quality of education, performance assessment of teachers should be done optimally by the school principals. The assessment of teachers' performance, on the other hand, is also influenced by the welfare of teachers in the form of adequate wages or monthly salary. Teachers' welfare can also determine the teachers' performance in their profession. If the assessment of teachers' performance is not comparable to the welfare of the teachers, and vice versa the welfare of teachers is not comparable with the assessment of teachers' performance, it can bring a serious doubt to the quality of education. This means that the assessment of teachers' performance and welfare of teachers and the improvement of the quality of educational outcomes have significant relationship or they have mutually reciprocal relationship. ${ }^{6}$

The school principals have a duty to assess the performance of teachers, and teachers have a duty to perform optimally in disciplinary action. ${ }^{7}$ Enforcing discipline to teachers to perform in high quality and discipline to the school principals to assess the teachers' performance certainly affects the achievement of the learning objectives and indicators and also increase students' learning motivation. ${ }^{8}$ In this case, teachers need to have some principles of teaching to improve the internal ability of students in stimulating in order to involve in learning activities. To increase the internal potential of the students, it can be done by applying appropriate learning strategies that enable students to achieve complete competencies. ${ }^{9}$ Consequently, learning

Maba, W., Perdata, I., \& Astawa, I. (2017). Constructing Assessment Instrument Models for Teacher's Performance, Welfare and Education Quality. International Journal Of Social Sciences And Humanities (IJSSH), 1(3), 88-96. doi:10.21744/ijssh.v1i3.59 
process can take place easily and the learning activities are not limited only to the events of the teacher, but it includes all events and activities which may have a direct effect on the successful learning process.

As an effort to improve the quality of the teachers in Indonesia, the government has provided teacher a professional allowance for those who have passed the teacher certification test, amounting to one month basic salary based on the Indonesian Ministry of Finance Regulation on Payment Procedures for Teachers and Lecturer Professional Benefits, Special Teacher Allowances and Lecturers, and Professors Honor Benefit (Ministry of finance regulation, Number 164 /PMK.05/2010). The teachers' professional allowance was intended to improve the welfare of teachers which as one of the indicators of teacher performance improvement in order to be able to enhance the quality of educational outcomes.10

Some field findings suggested that the performance of teachers were not in line with the expectations, although the welfare of teachers has improved in terms of wages or salary and other awards. ${ }^{16}$ Acceptance of teacher certification allowance amounting to one-month basic salary has not yet become an indicator of the improvement of the quality of educational outcomes. Most teachers have not used the allowance for teacher competence improvement and procurement of learning facilities and infrastructure at school but it was used for other purposes. This occurrence was in line the government expects and the regulations set by the authority.

Under Law Number 14 of 2005 regarding Teachers and Lecturers in article 15 suggests that: a) incomes above the minimum needs of teachers include basic salary, allowances attached to salary, and other income in the form of professional allowances, functional allowances, special allowances and benefits (b) teachers appointed by educational units organized by the Government or local government shall be paid in accordance with laws and regulations, c) teachers appointed by the educational unit held by the public was given a salary based employment agreement or collective bargaining agreement (Indonesian Government Regulation number 14 of 2005) regarding the teaching profession allowance will be paid by the government. 11

Based on the results of national examination year 2016/2017 showed that the quality of educational outcomes in elementary, junior high, and vocational schools were still not as expected. There were several factors that affect the quality of education outcomes, such as the inadequate assessment of teachers' performance and the inadequate teachers' welfare. Moreover, adds that the process of improving the quality of education can be done through the learning process standards and product standards of learning. ${ }^{12}$ Standard learning process with the eight (8) National Education Standards, namely (1) the standard content, (2) a standard process, (3) the standard of competency, (4), the standard of teachers and, (5) the standard of facilities and infrastructure, (6) Management standard, (7) Financing standard and (8) Education assessment standard (Government Regulation No. 13 of 2015 as the second amendment to Government Regulation Number 19 Year 2005).

Considering the phenomenon as described above, it is considered to be highly essential to construct valid and reliable assessment instrument models for the teachers' performance, teachers' welfare and education quality improvement. ${ }^{17,18}$ The well-constructed instrument models would certainly be very useful for the enhancement of education system and the attainment of educational objectives in all educational institutions in nationwide.

\section{Research Method}

The present study made use of a Research and Development Design investigating the developmental process of instrument assessment models for teachers' performance, welfare and education quality. The stages of the development of instrument assessment models were mainly carried out in six steps of sequence, namely: (1) analyzing the relevant documents, (2) planning assessment models, (3) designing the initial instrument of assessment models in the form of draft, (4) conducting test trial to the initial draft to limited number of subjects; (5) revising the initial draft based on the result of the test trial (6) re-examining the revised draft based on the results of the first trial. The steps Research and Development ( $R$ \& D) guided this study in 
conducting field study research to collect data on the test models. ${ }^{20,21}$ The data collected were then analyzed to construct a new model of the instrument of the assessment for teachers' performance, welfare and quality of education. The data were thoroughly analyzed by means of strict and in-depth analysis to establish valid and reliable findings. ${ }^{13}$ This was done to avoid the ambiguity of the research findings and the findings are in a real natural state.

\section{Results and Analysis}

The result of the research in the first year was in the form of an initial draft of the instrument assessment models for teacher performance, teachers' welfare and education quality improvement. The teachers' performance assessment instrument covers the identity of respondents, user response, 24 items, scoring formula, assessment criteria, and teachers' signature and the school principals' signature. The final draft of the assessment instrument for teachers' welfare consists of the identity of respondents, user answers, 25 items, formula scoring, criteria of judgment, and the signatures of teachers as well as the signature of the principals. The final draft of the assessment instrument for the improvement of the quality of educational outcomes consisting of the identity of respondents, user response, 17 items, ranking criteria and criteria of accreditation of average achievement test scores of the school and the average value of the national exam, and the principal's signature.

The results of the second year of research are in term of aspects of legibility, implementation, measurement, and achievement of a set of a model of teachers' performance assessment, teachers' welfare and the quality of education result. While the results of the feasibility and effectiveness of assessment instrument models were classified as a good category. Based on deductive and inductive academic studies in the implementation of 4D theory to construct an instrument model, it can be judged that the constructed assessment instrument models were classified as good.

There are several components that need to be considered in constructing the assessment instrument model. Most importantly is the comprehension of the nature of teachers' performance criteria. The teacher performance appraisal component consists of 4 (four) teacher competencies which are further elaborated into 24 (twenty) competency indicators, i.e. 10 (ten) indicators of pedagogic competence, 5 (five) indicators of personal competence, 4 (four) indicators of social competence and 5 (five) indicators of professional competence (Ministry of Education Regulation number 16 Year 2007).

Further elaboration of the teachers' competence are as follows: 1) understanding the characteristics of learners, potential learners, initial provision, and difficulty of learners, 2) mastering learning theories and principles of learning, applying approaches, methods, and creative learning strategies, 3) understand the principles of curriculum development, elaborating curriculum into the syllabus, developing lesson plans, determining learning media, and determining assessment of learning outcomes, 4) organizing learning lessons, implementing learning action plans, using learning media, 5) utilizing information and communication technology as a medium in learning, 6) facilitating the development of potential learners, applying various learning activities for the actualization and students' creativity, 7) communicating effectively, empathically and courteously with a distinctive and educative language to maintain the psychological condition of the students, 8) implementing assessment to see the student learning outcomes based on the principles of assessment, determining core assessment competencies, developing core competency assessment instruments, administering assessment results, and analyzing assessment results, 9) utilizing assessment results for learning improvement, using assessment results to determine and review the learning completeness criteria, following up the assessment results for remedial and enrichment activities, utilizing the results of the assessment of learning to improve the quality of learning and communicating the results of the assessment with stakeholders, 10) improving the quality of learning, utilizing the results of replication for improvement of learning and doing classroom action research to improve the quality of learning

Maba, W., Perdata, I., \& Astawa, I. (2017). Constructing Assessment Instrument Models for Teacher's Performance, Welfare and Education Quality. International Journal Of Social Sciences And Humanities (IJSSH), 1(3), 88-96. doi:10.21744/ijssh.v1i3.59 
Indicators of personality competence include: 1) acting in accordance with the norms of religion, law, social and culture of Indonesia, respecting the students without tribe, race, religion, area of origin and gender, acting according to religious norms, law, social actions applicable in society, 2) presenting oneself as honest, noble, and role models for students, behaving honestly, firmly and humanely, behaving in a way that reflects piety and noble character, 3) showing oneself as a steady, stable, mature, wise and wise person 4 ) showing a work ethic, high responsibility, sense of belonging to teachers and self-confidence and self-employed professionally, 5) upholding the professional code of ethics of teachers, apply the code of professional profession and behaving in accordance with the code of ethics of professional teacher

Indicators of social competence include: 1) being inclusive and objective towards students, other teachers, and the learning environment, not discriminating against students, other teachers, and parents because of differences in ethnicity, race, religion, socioeconomic status and gender, 2) communicating with other teachers, other scientific communities and parents and other communities in a polite, empathetic and effective manner, involving parents in overcoming student learning difficulties, 3) adapting to workplace environments in order to improve effectiveness as teachers, develop work programs to improve the quality of education in the region, 4) communicating with peers, scientific peers and other scientific communities through various media education and communicating the results of learning innovations to the educational profession.

Professional competency indicators include: 1) mastering the learning materials, structure, concepts, and patterns of science that support the subjects being taught, 2) mastering core competencies, basic competencies and elaborating basic competencies into specific indicators to determine learning objectives, 3 ) developing competencies of a number of indicators creatively, determining learning materials based on indicators and creating creative learning materials in accordance with the development of students, 4) develop professionalism in a sustainable manner by doing reflective actions on their own performance continuously, utilizing the results of reflection to improve teacher performance, carry out classroom action research to improve teachers' professionalism and following the progress of the times by learning from various sources, 5 ) utilizing information and communication technology in the learning process and selfdevelopment of subject teachers.

The quality of education outcomes through product standards of learning in primary and secondary education consists of learning outcomes assessment by teachers, assessment of learning outcomes by educational units and assessment of learning outcomes. Assessment of learning outcomes related to the quality of education is done in the form of a school exam and national exam (Regulation of Ministry of Education and Culture number 57 in 2015). School exam for several subjects including practical examinations conducted by educational units respectively, while the national exams in an elementary school conducted by Government of the Province. While the National Examination in junior high, high school and vocational high school conducted by the Central Government through the National Education Standards Agency commonly called BSNP. The results of school exam and national exam are reported in the range of 0 (zero) to 100 (one hundred) with attainment levels of competency in the following categories: a) very good, if the score is more than 85 (eighty-five) and less than or equal to 100 (one hundred), b) good, if the score is more than 70 (seventy) and less than or equal to 85 (eighty-five), c) sufficient, if the score is more than 55 (fifty-five) and less than or equal to 70 (seventy), and d) insufficient, if the score is less than or equal to 55 (fifty-five). This category is based on a standard used nationally and an indication of the learning achievement of the students.

All the standards as described above were strongly considered in constructing assessment instrument models for teachers' competence, teachers' welfare and education quality. The assessment models are still in the form of assessment drafts which need to be tried out to the designated schools. The results of the trial of the assessment administration then carefully analyzed to measure their degree of validity, reliability, and practicability to establish a set of 
assessment models. The try out process is considered to be important steps in this study and has been seriously planned to be carried out in the second year of the study.

\section{Conclusion}

Based on the analysis, it can be concluded that the implementation of the $4 \mathrm{D}$ theory of Research and Development study employed in constructing the assessment instrument models of teacher's performance, teachers' welfare and quality of educational outcomes could be concluded as a successful study in creating a set of assessment draft. Since the assessment draft was constructed solely based on the standard set the Indonesian government, therefore this assessment models are merely applying for the educational units in Indonesia. The assessment instrument for teachers' performance was designed to analyze the degree of teachers' performance in conjunction with teachers' standard and their ability to perform accordingly may affect their opportunity to get a higher salary. At the same time, the teachers' performance and better welfare may certainly improve the quality of education.

\section{Acknowledgements}

The authors would like to express their profound gratitude to all educators, teachers, and researchers for their help in conducting and writing this study. Deep sincere gratitude also goes to the authority of Education in Bali Province for the opportunity to study their education system. Special thanks are dedicated to all colleagues for their support, their contribution, and their valuable input during the writing of this paper. The authors also express their deepest gratitude to the Rector of Mahasaraswati Denpasar University, and the Chairman of Research, Community Empowerment of Mahasaraswati Denpasar University, and Dean of FKIP Mahasaraswati Denpasar University. Sincere gratitude also goes to the editors who have reviewed and approved this article to be published.

Maba, W., Perdata, I., \& Astawa, I. (2017). Constructing Assessment Instrument Models for Teacher's Performance, Welfare and Education Quality. International Journal Of Social Sciences And Humanities (IJSSH), 1(3), 88-96. doi:10.21744/ijssh.v1i3.59 


\section{References}

1. Hyde, J. S., \& Linn, M. C. (1988). Gender differences in verbal ability: A meta-analysis. View in (Google Scholar) (Scopus)

2. Astawa, I. N., Mantra, I. B. N., \& Widiastuti, I. A. M. S. (2017). Developing Communicative English Language Tests for Tourism Vocational High School Students. International Journal of Social Sciences and Humanities (IJSSH), 1(2), 58-64.

View in (Google Scholar)

3. Djaali, H., \& Muljono, P. (2008). Pengukuran dalam bidang pendidikan. Jakarta, Grasindo.

View in (Google Scholar)

4. Dantes, N. (2014). Landasan pendidikan: Tinjauan dari dimensi makropedagogis. Singaraja: Undiksha.

View in (Google Scholar)

5. Fitzpatrick, J. M., While, A. E., \& Roberts, J. D. (1997). Measuring clinical nurse performance: development of the King's Nurse Performance Scale. International Journal of Nursing Studies, 34(3), 222-230.

View in (Google Scholar) (Scopus)

6. Dhokhikah, Y., Trihadiningrum, Y., \& Sunaryo, S. (2015). Community participation in household solid waste reduction in Surabaya, Indonesia. Resources, Conservation and Recycling, 102, 153-162.

View in (Google Scholar) (Scopus)

7. Kristiansen, S. (2006). Decentralising education in Indonesia. International journal of educational development, 26(5), 513-531.

View in (Google Scholar) (Scopus)

8. Kerlinger, F. N. (1980). Metodologia da pesquisa em ciências sociais: um tratamento conceitual.

Epu.

View in (Google Scholar) (Scopus)

9. Maba, Wayan. 2017. The Implementation of Education National Standard in the Instrument of School Accreditation of Bali Province Education Authority. International Research Journal of Engineering, IT \& Scientific Research (IRJEIS). Vol. 3 Issue 4, July 2017, pages: 1-6 (2017). View in (Google Scholar)

10. Maba, W. (2017). Teacher's Perception on the Implementation of the Assessment Process in 2013 Curriculum. International Journal of Social Sciences and Humanities (IJSSH), 1(2), 1-9. View in (Google Scholar)

11. Maba, W., \& Mantra, I. B. N. (2017). An Analysis of Assessment Models Employed by The Indonesian Elementary School Teachers. International Journal of Social Sciences and Humanities (IJSSH), 1(1), 39-45.

View in (Google Scholar)

12. Mantra, I.B.N. 2017. Promoting Primary School Teachers' Competence through Dynamic Interactive Workshop and Partnership International Journal of Linguistics, Language and Culture (IJLLC). Vol. 3, No. 1, January 2017.

View in (Google Scholar) 
13. Nguyen, M. T. T. (2011). Learning to communicate in a globalized world: To what extent do school textbooks facilitate the development of intercultural pragmatic competence?. RELC Journal, 42(1), 17-30.

View in (Google Scholar) (Scopus)

14.Sri Widiastuti, I.A.Md. 2016. EFL Teachers' Beliefs and Practices of Formative Assessment to Promote Active Learning. The ASIAN EFL Journal. Volume 3.

View in (Google Scholar) (Scopus)

15.Sri Widiastuti, I.A.Md. 2017. Teachers' Understanding of Formative Assessment. Jurnal Bahasa dan Seni. Vol 45, No 1 Juni 2017.

View in (Google Scholar)

16. Billaiya, R., Malaiya, S., \& Parihar, K. S. (2017). Impact of Socio Economic Trends on Students in Quality Education System. International Journal of Social Sciences and Humanities (IJSSH), 1(1), 16-20.

View in (Google Scholar)

17.Suarta, I. M. (2017). Revitalization of Oral Literature Tradition of Balinese Society Based Character Values As Deradicalism Effort. International Journal of Social Sciences and Humanities (IJSSH), 1(3), 8-16.

View in (Google Scholar)

18. Jain, P. (2017). Cashless System of Colleges in India. International Journal of Social Sciences and Humanities (IJSSH), 1(3), 1-7.

View in (Google Scholar)

19.Yulyantari, L. M., \& Suryasa, I. W. (2016). Perancangan Pengembangan Media Pembelajaran Bahasa Indonesia Dengan Penerapan Metode Jigsaw. Jurnal Sistem dan Informatika, 10(1). View in (Google Scholar)

20.Suparsa, I. N., Mantra, I. B. N., \& Widiastuti, I. A. M. S. (2017). Developing Learning Methods of Indonesian as a Foreign Language. International Journal of Social Sciences and Humanities (IJSSH), 1(2), 51-57.

View in (Google Scholar)

21.Suryasa, I. W., Prayoga, I. G. P. A., \& Werdistira, I. W. A. (2017). An Analysis of Students' Motivation Toward English Learning As Second Language Among Students In Pritchard English Academy (PEACE). International Journal of Social Sciences and Humanities (IJSSH), 1(2), 43-50.

View in (Google Scholar)

Maba, W., Perdata, I., \& Astawa, I. (2017). Constructing Assessment Instrument Models for Teacher's Performance, Welfare and Education Quality. International Journal Of Social Sciences And Humanities (IJSSH), 1(3), 88-96. doi:10.21744/ijssh.v1i3.59 
Biography of Authors

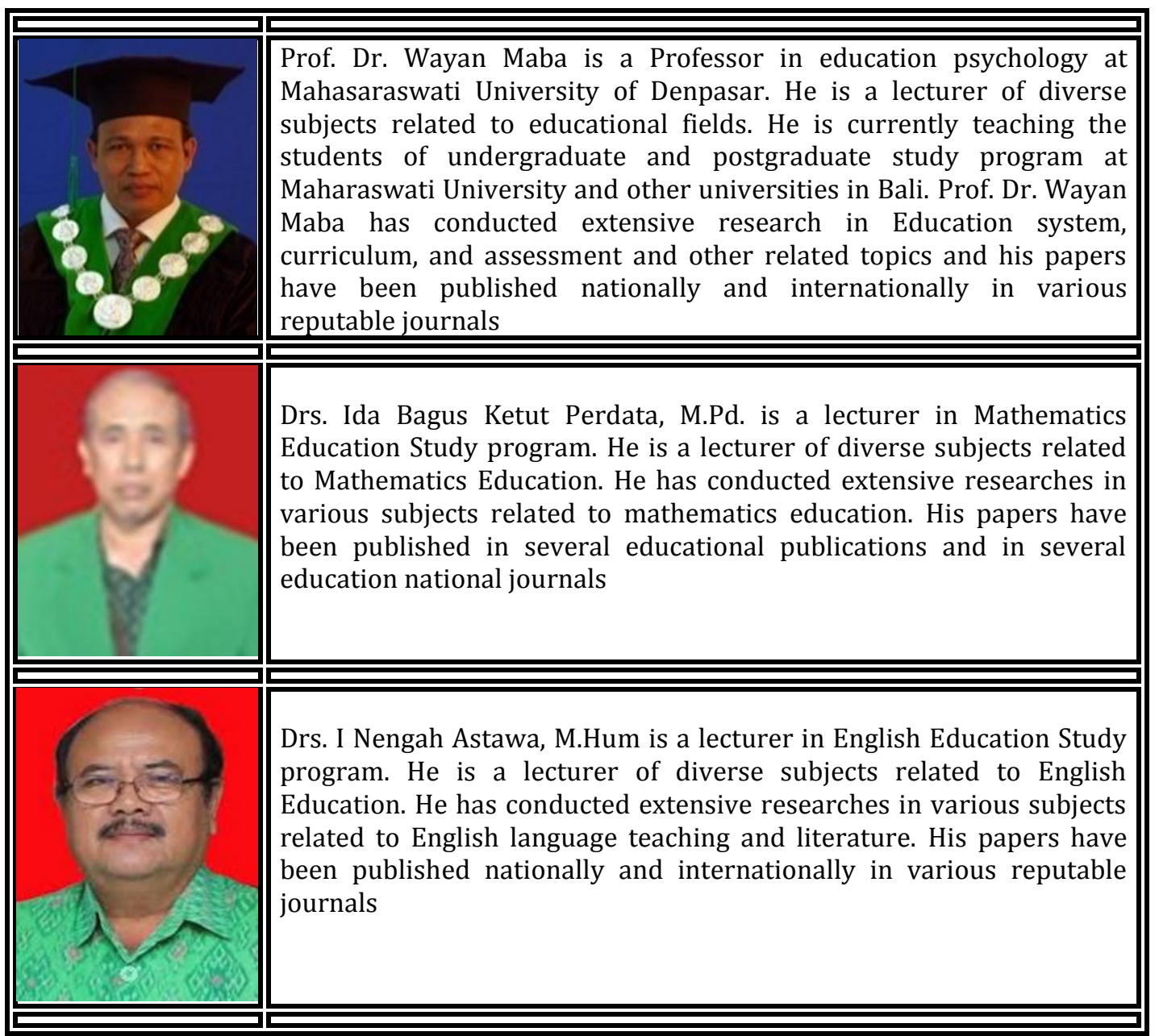

